JOURNAL OF SECURITY AND SUSTAINABILITY ISSUES

ISSN 2029-7017/ISSN 2029-7025 (online)

2020 Volume 9 January

http://doi.org/10.9770/jssi.2020.9.J(4)

\title{
Scopus
}

\section{EMPLOYEE MOTIVATION AND PERFORMANCE: DO THE WORK ENVIRONMENT AND THE TRAINING} MATTER?

\author{
Luedech Girdwichai $^{{ }^{*}}$, Chutikarn Sriviboon ${ }^{2}$ \\ ${ }^{1,2}$ Suan Sunandha Rajabhat University, Bangkok, Thailand, \\ E-mails: ${ }^{1 *}$ luedech.gi@ssru.ac.th (Corresponding author), ${ }^{2}$ chutikarn.sr@ssru.ac.th
}

Received: 10 March 2019; accepted 18 December 2019; published 30 January 2020

\begin{abstract}
The prime objective of the current study is to examine the impact of the employee motivation on the employee performance. Additionally, the study has also examined the mediating role of work environment and training on the relationship between employee motivation and the employee performance. The study has used the survey-based methodology and the data is gathered form the academic staff in the ten leading business schools in Indonesia. The data is gathered with the aid of questionnaire and the response rate turned out to 62.3 percent. The SEM-PLS is employed for the data analysis. The results show that there was significant relation between employee performance and employee motivation. It also reported that training had a positive but moderate relationship to employee performance. The findings highlighted areas which organizations should focus on in order to enhance employee performance. Healthy and positive working environment have been found to enhance performance. The work environment fails to mediate the relationship between the employee motivation and the employee performance. The findings highlighted areas which organizations should focus on in order to enhance employee performance. Healthy and positive working environment have been found to enhance performance. The findings suggest that the introducing a relax zone, for instance, can encourage employees to generate ideas and relax their mind. Organizations should find out what really motivate employees and take necessary action to ensure employees will be constantly motivated at the workplace.
\end{abstract}

Keywords: employee motivation; training; employee performance; work environment; higher education; Indonesia

Reference to this paper should be made as follows: Girdwichai, L., Sriviboon, C. 2020. Employee motivation and performance: do the work environment and the training matter? Journal of Security and Sustainability Issues, 9(January), 42-54. http://doi.org/10.9770/jssi.2020.9.J(4)

JEL Classifications: I25

\section{Background}

Behind any successful organization human resource plays an important role as a backbone (Sriviboon \& Jermsittiparsert, 2019). According to the literature the in organization the competitive advantage can be increased or sustained by a well-managed human resource (Sriekaningsih \& Setyadi, 2015; Kerdpitak \& Jermsittiparsert, 2019). With the help of strategic management of HR, the organization can accomplish and use its resources at optimal level, which will make a contribution in leading the organization towards continues and effective accomplishment. van Woerkom et al. (2016) has suggested that any organization can achieve its goals by utilizing its resources at optimal level with a help of good management of human resource. The employee's performance is affected by the goals of organization, the organization can accomplish its goals only when its employees are giving well performance. Different factors including job satisfaction, employee engagement, salary, training, workplace environment and motivation can influence the employee performance ( Davydenko et al., 2017; Al-Kahtani, 2018; Kiruja \& Mukuru, 2018; Lorincová et al., 2019; Bernardi, 2019). 


\section{JOURNAL OF SECURITY AND SUSTAINABILITY ISSUES}

ISSN 2029-7017/ISSN 2029-7025 (online)

2020 Volume 9 January

http://doi.org/10.9770/jssi.2020.9.J(4)

Organizations are subsumed in today's unstable, uncertain and unpredictable environment with long-term survivability and sustainability in question. The business operations are affected with the interacted volatile environment which eventually effects the overall performance and profitability of the organization. In global financial crises of 2008the Malaysian banks and financial sectors were predicted to have a declining performance but they were not able to decide to the 1997-1998 Asian financial crisis levels(Almeida et al., 2015). On the performance of financial institutions there is significant impact of the global financial crises, world economy and thought-provoking economic environment (van Woerkom et al., 2016). In the national economic development and economic growth of Malaysia there is an important role of its banking industry. The banking industry is aligned with the nation's economic scenario because this industry also makes its contribution in the revenue of country. The distribution of financial resources and efficient and effective of banking system is playing an important role in transforming the Malaysia in becoming a high-income economy and having a prominent role of intermediation of funds with in the region and other developing economies (Baskaran et al.,2017). There is a continuous threat to the overall performance of the banks by the external environment (Tvaronavičienè et al., 2018; Masood et al., 2019). It must highlight the specific areas and work inside the internal environment, where there is a control of initiative implementation and strategic planning for the productivity enhancement and should also focus on polices of human resource for enhancing the work force quality for becoming a more competitive economy (Sriekaningsih \& Setyadi, 2015).

For the continuous development the bank must work on aligning the objectives and goals of organization and employee performance and motivate their employees by developing the positive work environment and proper trainings. According to the Mayer and Roberta (2017) as mostly internal factors are under controlled by the organization so the organizations should pay more attention to identify and deal with the internal environment. According to Kiruja and Mukuru (2018) there are some factors like effective training, employee motivation, workplace environment, structures, systems and processes can affect the individual performance positively or negatively. He also stated that the employees who are motivated work hard and always be loyal to their organizations. And the employees who are trained well will perform better. So, the internal environment must be planned in this way that it provides opportunity to share ideas and exchange the knowledge, and formal and informal interactions must be encouraged at work place to increase the performance (Almeida et al.,2015). Best employee performance lead towards successful business. For the effective job performance, the employees should have motivation and enough trainings to provide them the important capabilities which will help then to perform their job. For the performance and development of employees the important factors are satisfiers or motivators (Jalloh \& Jalloh, 2016).

Besides the work environment, employee's behavior, employee motivation and training the job performance can be controlled by the organization. (Zhang, 2019), has stated that the opportunity to voice out the concerns of employees, credible and consistent management, respectful treatment, satisfactory benefits and compensation, job security, comfortable working conditions a practical workload and a healthy work environment are not motivational factors rather these are basic requirements. So, this has filled this gap that either training, work environment and employee motivation are main factors that must be considered by the bank for increasing the employee performance. 
JOURNAL OF SECURITY AND SUSTAINABILITY ISSUES

ISSN 2029-7017/ISSN 2029-7025 (online)

2020 Volume 9 January

http://doi.org/10.9770/jssi.2020.9.J(4)

\section{Literature Review}

\subsection{Employee performance}

Some evidences are rising that HR management plays an important role for retaining the exiting high-quality work force. Different studies regarding the practices of HR management have revealed that absenteeism and turn over can be reduced which ultimately increase the quality work and with high performance with the help of good practices of HR. (Guest et al., 2017). It is also suggested that there is an important role in employee retention by the HR management. Boer et al.(2017), had made a study on the issue of high performance and the strategy of organization related to employee retention was primarily started by Australia, Asia, Europe and US. A business can never exit without the human capital just as financial capital is important for the establishment of business (Marvel et al.,2016).The employee work for company and help in performing the important task for the proper functioning of the company and they also accountable for the growth and required profit of the company (Drucker, 2017). According to the Chhotray et al.(2018) employee motivation means empower to the employees for leading the company towards the competitiveness. And for the employees the empowerment and motivation are important to stay in company for long period of time company (Jacoby, 2018)

\subsection{Employee Motivation}

As per the study of Mikkelsen et al. (2017), "the motivation concept referred to internal factors that impel action and to external factors that can act as inducements to action". They further suggested that direction, intensity, and duration are the three-action influenced by motivation. Thus, understanding different employees' motivational style will help to explain and predict the affect, cognition, and behavior patterns that are displayed by different employee (Hsiung \& Tsai, 2017). Kanfer et al.(2017) argued that some common words like goals, incentives, needs, aims, wishes, wants or desires are included in motivation. According to Cameron and Green (2019) the inner force which gives energy to the individuals for the accomplishment of organizational and personal goals is known as motivation. Hence, work motivation has been referred as the process that contributes to the initiation and maintaining goal-directed performance(Larsson et al., 2018). The importance of achievement motivation in work is seen as focusing in intrinsic motivation, the level of the "motivational state in which individuals is attracted to and energized by the task itself might be obtained (Beal, 2017). This was supported by Jacoby (2018) who suggested that people can be motivated by the nature of work itself. According to the Cameron and Green (2019) the acquisition of abilities and skills of people can be affected by the motivation. Thus, through mastery and performance goals, motivation will prompt a focus on self rather than on task (Durodolu, 2016).

As per the study of Breaugh et al. (2018) employee motivation can be of two types the first type is Extrinsic and the other one is intrinsic motivation. The people who have extrinsic motivation are the one who never interested in doing any kind of odd jobs, but they get ready just for the sake of getting some extra incentives such as wages or promotion, some praises and appreciations (Larsson et al., 2018). Whereas the people with intrinsic motivation are internally motivated or are self-motivated people, and for the performing their job well they just don't need extra praise wage or any other rewards. They actually enjoy doing the challenging jobs and complete their targets efficiently (Jacoby, 2018). Though the best form of motivation is intrinsic one because it has long term and strong effects on employees because according to the (Vanek, 2017) the intrinsic motivation cannot be imposed by the management on employee as it is inherited in employees. According to another study of Froese et al.(2016), the turnover intention of the employees is also depending on effects of individual background. Through the motivation the employee turnover can be decreased. 


\section{JOURNAL OF SECURITY AND SUSTAINABILITY ISSUES}

ISSN 2029-7017/ISSN 2029-7025 (online)

2020 Volume 9 January

http://doi.org/10.9770/jssi.2020.9.J(4)

According to the Cook and Artino Jr (2016) the goals, incentives, needs or wants, aims and wishes or desires are the common enclosure of words that motivation have. So, for the achievement of goals the individual must be energetic and motivated effectively and focused on accomplishing their goals, and for the realization of objectives they agree to utilize their energies for long time period. Moodley and Hove (2018) have found that the employee turnover can be affected by the employee motivation, and they also stated that the demotivated employee tends to leave the organization. The organizational commitment job satisfaction and the employee motivation are the important factors which plays an important role in employee turnover. In an organization the most dedicated employees can give the best performance. There are different factors which effects the employee performance such as structure of organization, job security, trainings, compensations, employee satisfaction and motivation and appraisals, but the current study will focus on employee motivation as the employee performance can be highly affected by the employee motivation._According to the Froese et al. (2016) in an organization the managers can increase the effectiveness of job administration among other employees by having the employee motivation as procedure.

\section{Working Environment}

For the explanation of work environment, a lot of studies were conducted in different aspects like employee retention job satisfaction organizational commitment employee turnover and job involvement. According to the Kim and Yun (2015) in employee retention the most important factor is the work environment. As per the study of Abhigna and Subramanyam (2017) we generally discuss the work environment in industrial point of view and focused on different aspects like heavy lifts the exposure of toxic substances and noise. The different characteristics of work environment in production and service sector are different which is quite interesting because in service sector the organizations staff directly deals with the customers or consumers. Interaction with customers depends on the nature of business or job it may increase or decrease accordingly. And these interactions of employees and clients ultimately move from physical dimension to psychological. The psychological work environment contains decision and latitude, stress, support and workload.

In an organization for keeping the employee committed it is very important to recognize the employee needs and give them healthy work environment. Brum (2007)has stated that when people feel that they are making contribution in the performance of organization then they stay for long in an organization and strive to work because of positive work environment. The talented employees of these organizations drag together for achieving the organizational goals. According to the study of Kim and Yun (2015) in the decision making of employee either to stay in or leave the job there is an important role of work environment which is also an important factor in employee retention. For example, for the physical and psychological health of employees the noisy work environment is harmful and reduce their productivity. The speech isolation shorts are the abundant audio complains like over hearing the discussion of people and feel the same. Reduction in stress and anxiety are helpful for the environment of an organization. Recognition of responsibilities, work clarity involvement in making different decisions, work challenges, coworkers support and efficient managers are included in work environment. The employee leads to look forward for the new opportunities because the lack of such environment. In this environment the employee feels connected with organization in all aspects. The employees need an environment where they have continuous learning, improvement in their skills provision of certification and higher studies etc. The work life balance includes wellness of employees, free vacations, alteration of work schedule telecommunication and flexible hours, which can be provided by the organization.

\section{Training}

According to Cloutier et al.(2015) employee retention the most important factor is investment in training the employee. There is an incentive for the organization to invest for training of those employees who can contribute in increasing the output of organization. For the talented employees' organizations are the development escalation, 


\section{JOURNAL OF SECURITY AND SUSTAINABILITY ISSUES}

ISSN 2029-7017/ISSN 2029-7025 (online)

2020 Volume 9 January

http://doi.org/10.9770/jssi.2020.9.J(4)

with the help of proficiency analysis, input of employee interest, and for the formulation of actions and plans the multisource capabilities appraisal and development s required. According to Riley et al. (2017) in the form of trainings individuals and firms make investments on human capital. The employee skills can be increased with the help of trainings. After hiring of new employees, the organization must start a training program to increase their skills. Kim and Yun (2015) has stated that there is perception that employees want to acquire new knowledge skills for the job application and share with their colleagues. According to the study of Abhigna and Subramanyam (2017) employees can get specialized skills and different techniques from trainings which help them in rectifying the performance deficiencies. Whereas the abilities and skills provided by the development are the one which organization will need in future. Improvement in basic literacy, problem solving, technological knowledge and interpersonal communication all are the part of skill development.

According to the Riley et al. (2017) in market for meeting the global challenges of market, it is important for organizations to provide modern knowledge to their employees to increase their performance. According to the survey of Kim and Yun (2015) regarding training large manufacturing firm have high tendency to provide trainings as multinational firms train their employees with high performance or with approach of flexible production. According to the literature the organizations or companies which spends more on human resources for the establishment of high performance can easily retain their talented staff. The firms which are more trained to tackle the advanced technical changes have shown progress in their output as compare to the firms who never face any competitors in past. Abhigna and Subramanyam (2017) has stated that when organizations give more benefits and adopt the innovative techniques to train its employees as compare to other firms in the market, they retain their staff for long time period. According to Achieng'Nyaura and Omwenga (2016), for employees, training is basically a sign of organizational commitment. It's the part of agreement in leading firms' that career and skill development, and an inclusive range of trainings are the important factors for retention and attraction to form a flexible strategy of firm for the success of technological and sophisticated employees in an automatic economy. According to the Brum (2007) trainings are inversely related with the employee turnover ratio means if number of training increased it will lower the turnover rate. Its means that if a worker stay long in organization will acquire number of trainings. As per the opinion of workers productivity can be increased with the help of skill related trainings. Organization will increase employee wages if they have high productivity which ultimately help in employ retention. In employee retention the main factor is training because it is helpful in reducing the turnover rate. Organizations should give a chance to their employees to enhance and improve their skills with the help of trainings. A lot of firms be afraid that when their employees will be well trained, they will start searching other opportunities and quit their job. The resources on which the organizational success depends should not be limited. Development and carrier growth are the important part of every one's career. In employee growth the key factor which an employee looks for himself or herself is work profile, which must not be too high or too low. With the help of trainings, the employee can increase their performance with advanced skills (Dhar, 2015). Whereas the development is a process to provide different capabilities that can be helpful for employees and organization in future (Teece et al., 2016).

Based on the literature reviewed the study has drawn the following hypothesis

H1: EMM has significant impact on the EMP.

H2: EMM has significant impact on the WE.

H3: EMM has significant impact on the TR.

H4: WE have significant impact on the EMP.

H5: TR has significant impact on the EMP.

H6: The WE mediate the relationship between the EMM and EMP.

H7: The TR mediates the relationship between the EMM and EMP. 
JOURNAL OF SECURITY AND SUSTAINABILITY ISSUES

ISSN 2029-7017/ISSN 2029-7025 (online)

2020 Volume 9 January

http://doi.org/10.9770/jssi.2020.9.J(4)

\section{Methodology}

For the purpose of current research, total 300 questionnaires were distributed and subsequently derived 250 questionnaires from the respondents. Due to incomplete questionnaires and missing information we discarded 6 questionnaires, resulting in 244 usable questionnaires, with $81.3 \%$ of response rate for carrying out the data analysis. Since the data has been collected through self-administered method, therefore no test was performed to check the biasness. The questionnaires were distributed by hand to each survey participant with a one-week time to fill and send back to the researcher for further data processing. In addition, a conformity test has not been performed to check for nonconformities between non-respondent and respondent, because of the research methodology chosen for this study and because all the distributed questionnaires were received within the expected time. The Partial least square (PLS) was selected for statistical analysis of the data. This method was chosen because, firstly, this method demands less regarding sample size, as compared to AMOS or other techniques; secondly, it is suitable for complex models involving multiple constructs, and have no strict requirement for normally distributed data; and lastly, PLS is considered to be an ideal technique to describe and forecast model constructs using structural equation modeling (Hair et al., 2014). Thus, PLS-SEM was chosen to examine the collected data and to provide supporting evidence for the hypotheses. The measurement of the variable of the study is taken from the prior studies

\section{Results}

Hair et al. (2014) described PLS as a modeling approach which particularly aims at describing as well as maximizing the variance in the dependent latent construct. Generally, a two-staged approach is used to apply PLS. The first stage involves assessing reliability and validity of measurement model, and second stage involves structural model estimation. The measurement model under PLS-SEM context is also termed as the outer-model, which can further be classified as formative and reflective path-modeling (Becker et al., 2012). The goodness of measurement model was checked to confirm the validity and reliability of measuring items involved in this research. According to Hair et al. (2014), the validity and quality of latent constructs is determined by estimating each construct's convergent and discriminant validity. A construct's validity is described as the extent to which a variable's operational definition truly reflects and interprets its theoretical meaning. The measurement model of the current study is shown in the figure 1 below. Outer loading is presented in Table 1.

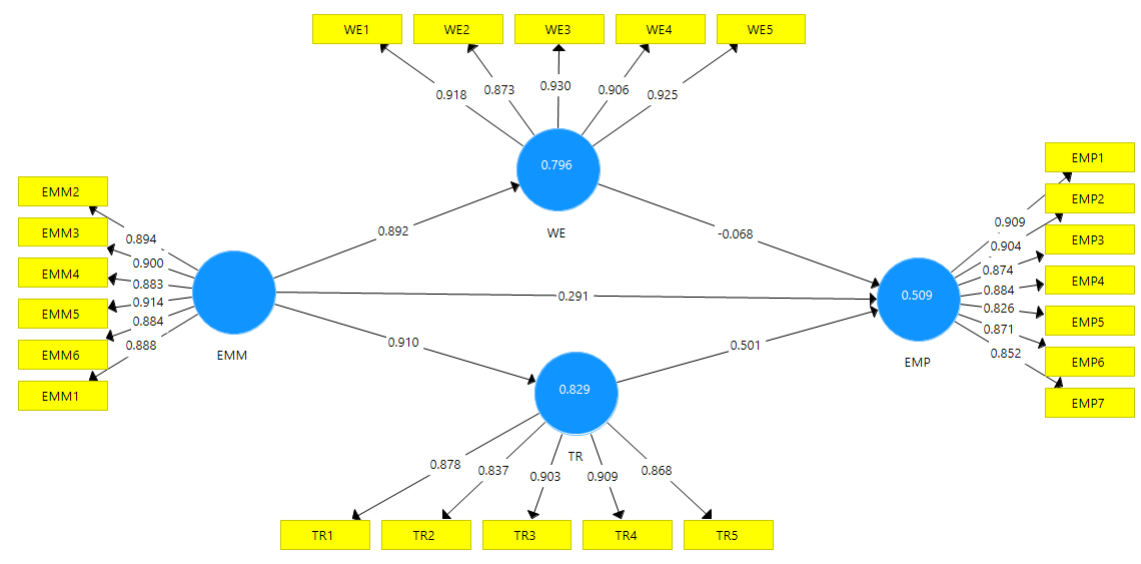

Figure 1. Measurement Model

Table 1. Outer Loading 
JOURNAL OF SECURITY AND SUSTAINABILITY ISSUES

ISSN 2029-7017/ISSN 2029-7025 (online)

2020 Volume 9 January

http://doi.org/10.9770/jssi.2020.9.J(4)

\begin{tabular}{|l|l|l|l|l|}
\hline & EMM & EMP & TR & WE \\
\hline EMM2 & 0.894 & & & \\
\hline EMM3 & 0.900 & & & \\
\hline EMM4 & 0.883 & & & \\
\hline EMM5 & 0.914 & & & \\
\hline EMM6 & 0.884 & 0.909 & & \\
\hline EMP1 & & 0.904 & & \\
\hline EMP2 & & 0.874 & & \\
\hline EMP3 & & 0.884 & & \\
\hline EMP4 & & 0.826 & & \\
\hline EMP5 & & 0.871 & & \\
\hline EMP6 & & & & \\
\hline EMP7 & & & 0.878 & \\
\hline TR1 & & & 0.837 & \\
\hline TR2 & & & 0.903 & \\
\hline TR3 & & & 0.909 & 0.925 \\
\hline TR4 & & & 0.868 & \\
\hline TR5 & & & & \\
\hline WE1 & & & & \\
\hline WE2 & & & & \\
\hline WE3 & & & & \\
\hline WE4 & & & & \\
\hline WE5 & & & \\
\hline EMM1 & & & \\
\hline
\end{tabular}

As previously mentioned, the convergent and discriminant validity of the constructs were established through performing a confirmatory factor analysis (CFA). The convergent validity is defined as a contract or arrangement among measures of the similar construct (Bagby et al., 1994). It shows those set of indicators that are regarded as original constructs which can be determined through their uni-dimensionality. Thus, convergent validity was assessed by determining the factor loadings, average variance extracted (AVE) and the composite reliability (CR) (Hair et al., 2011). Finally, the average variance extracted (AVE) was calculated for establishing convergent validity. Hair et al. (2014) suggest that AVE refers to the extent the latent construct can explain the change in items of the same construct. Fornell \& Larcker (1981) recommend AVE to assess convergent validity, and the AVE >0.50 indicates that more than $50 \%$ change in indicator is explained by the respective latent variables (Hair et al.,2014). Reliability is presented in below in Table 2 . 
JOURNAL OF SECURITY AND SUSTAINABILITY ISSUES

ISSN 2029-7017/ISSN 2029-7025 (online)

2020 Volume 9 January

http://doi.org/10.9770/jssi.2020.9.J(4)

Table 2. Reliability

\begin{tabular}{|l|l|l|l|l|}
\hline & Cronbach's Alpha & rho_A & CR & (AVE) \\
\hline EMM & 0.950 & 0.950 & 0.960 & 0.799 \\
\hline EMP & 0.949 & 0.950 & 0.958 & 0.765 \\
\hline TR & 0.926 & 0.928 & 0.944 & 0.773 \\
\hline WE & 0.948 & 0.950 & 0.960 & 0.829 \\
\hline
\end{tabular}

Hair et al.(2014) defined discriminant validity as the degree that a construct is uncorrelated with different measures. According to Sekaran and Bougie (2011), it refers to a situation where two distinct concepts possessing varied features are uncorrelated. Thus, the discriminant validity (DV) shows the uniqueness of varied and distinct constructs. For the purpose of establishing a construct's adequate discriminant validity, van Woerkomet al. (2016) suggested two different methods, namely, the cross loadings and the Fornell-Larcker criterion. Discriminant validity is presented below in Table 3.

Table 3. Discriminant validity

\begin{tabular}{|l|l|l|l|l|}
\hline & EMM & EMP & TR & WE \\
\hline EMM & 0.894 & & & \\
\hline EMP & 0.687 & 0.875 & & \\
\hline TR & 0.810 & 0.704 & 0.879 & \\
\hline WE & 0.892 & 0.651 & 0.816 & 0.911 \\
\hline
\end{tabular}

Afterwards, a path-analysis was employed to test and validate the set of proposed hypotheses. Therefore, at first stage of this analysis, the inner model was determined. The partial least square (PLS) is basically a prediction and variance-based approach that aims to test the hypothesized relationships and the building of supporting theoretical framework. The structural model of the current study is shown in the figure 2 below.

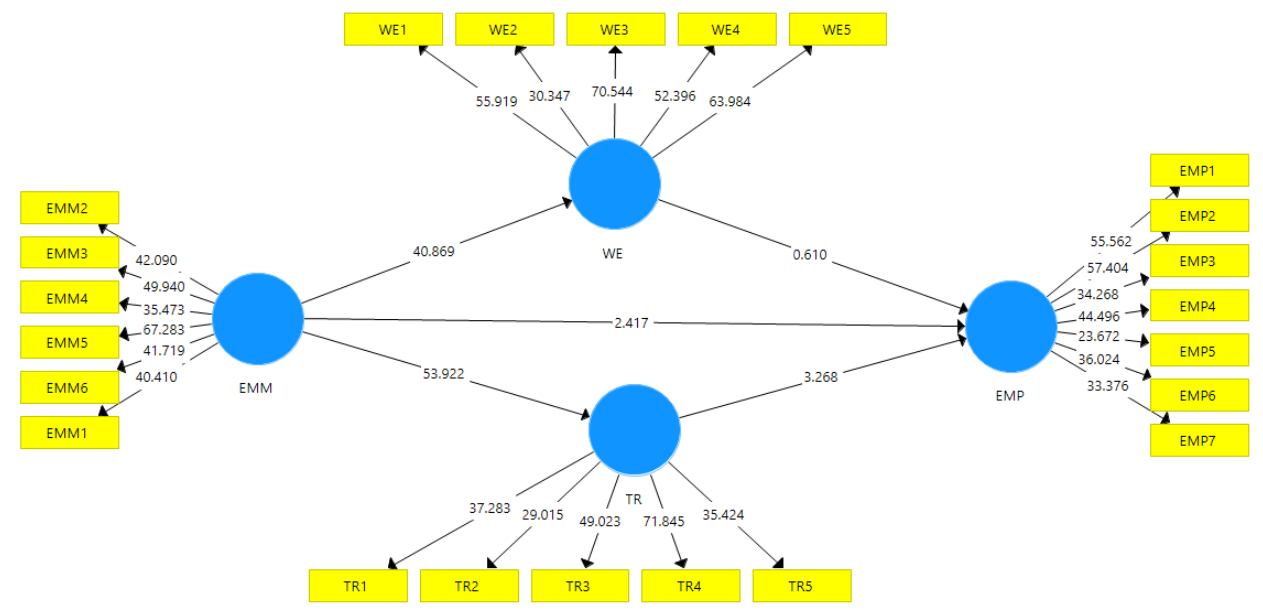

Figure 3. Structural Model 
Following Wong (2013) suggestion in current research, the structural model was determined through PLS-SEM algorithm and bootstrapping, where bootstrapping is a non-parametric re-sampling approach that is generally employed under PLS to analyze the significance of estimated parameters. The purpose of estimating structural relationships involved in the structural model is to check the relationships between the variables and to test the proposed hypotheses. Thus, we performed a bootstrapping procedure to obtain the model's t-statistics, by employing 500 resamples. The findings of the study have highlighted that exp WE -> EMP, all the paths EMM -> EMP, EMM -> TR, EMM -> WE, and TR -> EMP are significant. Direct Relationships are presented in Table 4.

Table 4. Direct Relationships

\begin{tabular}{|l|c|c|c|l|l|}
\hline & $(\mathbf{O})$ & $(\mathbf{M})$ & $(\mathbf{S T D E V})$ & $(\mid \mathbf{O} /$ STDEV $)$ & P Values \\
\hline EMM $->$ EMP & 0.687 & 0.690 & 0.069 & 9.923 & $\mathbf{0 . 0 0 0}$ \\
\hline EMM $->$ TR & 0.910 & 0.910 & 0.017 & 53.922 & $\mathbf{0 . 0 0 0}$ \\
\hline EMM -> WE & 0.892 & 0.892 & 0.022 & 40.869 & $\mathbf{0 . 0 0 0}$ \\
\hline TR -> EMP & 0.501 & 0.498 & 0.153 & 3.268 & $\mathbf{0 . 0 0 1}$ \\
\hline WE -> EMP & -0.068 & -0.056 & 0.111 & 0.610 & $\mathbf{0 . 2 7 1}$ \\
\hline
\end{tabular}

The study has also examined the mediating role of the TR, and WE in the relationship between EMM, and EMP. The findings of the study have revealed the fact that the TR mediates the relationship between EMM, and EMP whereas the WE fail to mediate the relationship between EMM and EMP. Mediation is presented in Table 5.

Table 5. Mediation

\begin{tabular}{|l|c|c|l|l|l|}
\hline & $(\mathbf{O})$ & $(\mathbf{M})$ & $(\mathbf{S T D E V})$ & $(|\mathbf{O} / \mathbf{S T D E V}|)$ & P Values \\
\hline EMM -> TR -> EMP & 0.456 & 0.453 & 0.141 & 3.243 & $\mathbf{0 . 0 0 1}$ \\
\hline EMM -> WE -> EMP & -0.060 & -0.049 & 0.099 & 0.607 & $\mathbf{0 . 2 7 2}$ \\
\hline
\end{tabular}

The R-square or coefficient of determination value ranges between 0 and 1 , the greater the value i.e. close to 1 , the higher the forecasted accuracy level. The $\mathrm{R}^{2}$ value is considered to be weak if it is equal or less than 0.25 , it is considered as moderate if it is equal to 0.50 and substantial if it exhibits a value equal or above 0.75 . R-square is presented in Table 6.

Table 6. R-square

\begin{tabular}{|l|l|}
\hline & R Square \\
\hline EMP & 0.509 \\
\hline TR & 0.829 \\
\hline WE & 0.796 \\
\hline
\end{tabular}

To explain the predictive ability of the conceptual model drawn and proposed in this research we have used the blindfolding procedures. The blindfolding is mapped in the figure 4 below. 


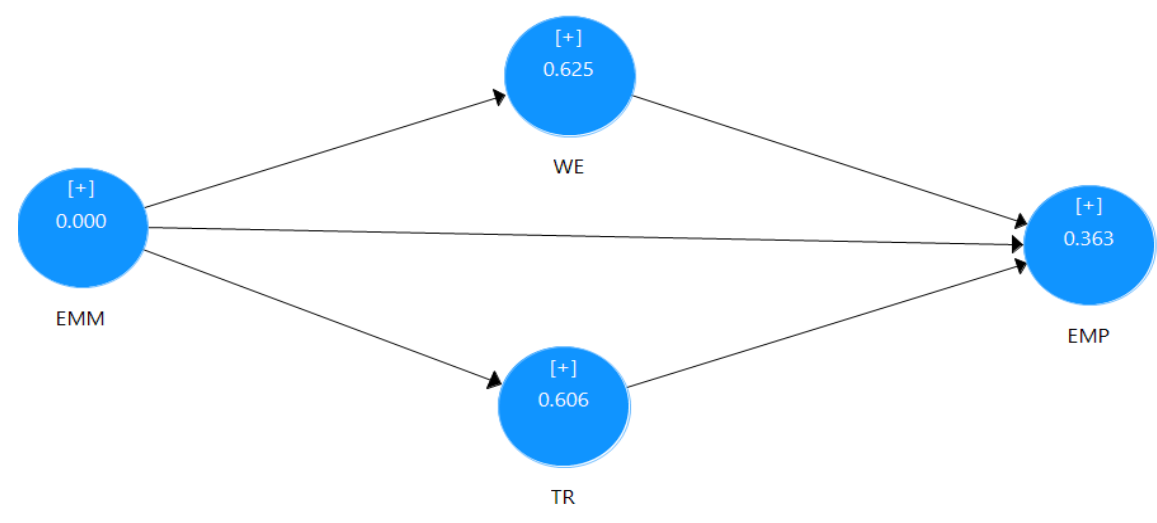

Figure 4. Blindfolding

The findings of the blindfolding procedures have revealed that there is no issue of predictive relevance in the currents study as all the value sin the table are above zero. Q-square is presented in Table 7.

Table 7. Q-square

\begin{tabular}{|l|l|l|l|}
\hline & SSO & SSE & $\mathbf{Q}^{2}$ (=1-SSE/SSO) \\
\hline EMM & $1,302.000$ & $1,302.000$ & \\
\hline EMP & $1,519.000$ & 967.143 & 0.363 \\
\hline TR & $1,085.000$ & 427.415 & 0.606 \\
\hline WE & $1,085.000$ & 406.699 & 0.625 \\
\hline
\end{tabular}

\section{Conclusion}

The results show that there was significant relation between employee performance and employee motivation. It also reported that training had a positive but moderate relationship to employee performance. Similar findings were found from past studies. Employee motivation was found to have an impact on employee performance(Moodley \& Hove, 2018). They found that demotivated employees tend to be dissatisfied, absent from work or leave the organizations. Absenteeism affects employees ${ }^{\text {ee }}$ job performance. The best performance is achievable with most dedicated employees that can only be completed through employee motivation within an organization. Employees perform well on the job mostly depends on different factors such as depend on many factors like organizational structure, job security, trainings, compensations, employee satisfaction and motivation appraisals and performance, but the current study will focus on employee motivation as it affects the employee performance. Vanek (2017) said that managers can increase the effectiveness of job administration among other employees in the organizations with having employee motivation as procedure.

The findings highlighted areas which organizations should focus on in order to enhance employee performance. Healthy and positive working environment have been found to enhance performance. Introducing a relax zone, for instance, can encourage employees to generate ideas and relax their mind. For example, the management of Google company office prepared a relax zone for the employees and the theme chosen for the office is so relaxing and there are no compartments there because the management wanted to create a good environment for the employees. The relationship between the office mates is also good. The company must be aware of the importance of training for 


\section{JOURNAL OF SECURITY AND SUSTAINABILITY ISSUES}

ISSN 2029-7017/ISSN 2029-7025 (online)

the employees. Employees must attend any training that can help in developing their career and getting a good performance in their work. This will lead to job satisfaction for their management. For example, employees who attended training should share the knowledge. Motivation is another aspect which the organization must consider as it affects employeese satisfaction and performance. Organizations should find out what really motivate employees and take necessary action to ensure employees will be constantly motivated at the workplace.

\section{References}

Abhigna, J., \& Subramanyam, K. (2017). Review of skill set requirement for proffessional carrier. International Journal of Pure and Applied Mathematics, 117(19), 423-431.

Achieng'Nyaura, L., \& Omwenga, D. (2016). Factors Affecting Employee Retention in the Hotel Industry in Mombasa County. Imperial Journal of Interdisciplinary Research, 2, 12.

Almeida, H., Kim, C. S., \& Kim, H. B. (2015). Internal capital markets in business groups: Evidence from the Asian financial crisis. The Journal of Finance, 70(6), 2539-2586. https://doi.org/10.1111/jofi.12309

Al-Kahtani, N.S. (2018). Perception of private telecom employees towards unfair HRM practices: an empirical investigation. Entrepreneurship and Sustainability Issues, 5(4), 957-966. http://doi.org/10.9770/jesi.2018.5.4(18)

Bagby, R. M., Taylor, G. J., \& Parker, J. D. (1994). The twenty-item Toronto Alexithymia Scale-II. Convergent, discriminant, and concurrent validity. Journal of psychosomatic research, 38(1), 33-40. https://doi.org/10.1016/0022-3999(94)90006-X

Baskaran, A., Tang, M., Thiruchelvam, K., Shahabudin, S. M., \& Chan, T. S. (2017). Social entrepreneurship and inclusive growth: Attributes, perceptions and roles of business incubators and intermediaries in Malaysia. Science, Technology and Society, 0971721819873186. https://doi.org/10.1177\%2F0971721819873186

Beal, M. A. (2017). How Does Goal Setting Impact Intrinsic Motivation And Does It Help Lead To Enhanced Learning At The Kindergarten Level? https://digitalcommons.hamline.edu/cgi/viewcontent.cgi?article=5314\&context=hse_all

Becker, J.-M., Klein, K., \& Wetzels, M. (2012). Hierarchical latent variable models in PLS-SEM: guidelines for using reflective-formative type models. Long Range Planning, 45(5-6), 359-394. https://doi.org/10.1016/j.1rp.2012.10.001

Bernardi, A. (2019). The capability approach and organizational climate as tools to study occupational health and safety. Insights into Regional Development, 1(2), 155-169. https://doi.org/10.9770/ird.2019.1.2(6)

Boer, H., Berger, A., Chapman, R., \& Gertsen, F. (2017). CI Changes from Suggestion Box to Organisational Learning: Continuous Improvement in Europe and Australia: Continuous Improvement in Europe and Australia: Routledge. https://doi.org/10.4324/9781315198286

Breaugh, J., Ritz, A., \& Alfes, K. (2018). Work motivation and public service motivation: Disentangling varieties of motivation and job satisfaction. Public Management Review, 20(10), 1423-1443. https://doi.org/10.1080/14719037.2017.1400580

Brum, S. (2007). What impact does training have on employee commitment and employee turnover?

Cameron, E., \& Green, M. (2019). Making sense of change management: A complete guide to the models, tools and techniques of organizational change: Kogan Page Publishers.

Chahal, H., Jyoti, J., \& Rani, A. (2016). The effect of perceived high-performance human resource practices on business performance: Role of organizational learning. Global Business Review, 17(3_suppl), 107S-132S. https://doi.org/10.1177\%2F0972150916631193

Chhotray, S., Sivertsson, O., \& Tell, J. (2018). The roles of leadership, vision, and empowerment in born global companies. Journal of International Entrepreneurship, 16(1), 38-57. https://doi.org/10.1007/s10843-017-0201-8

Cloutier, O., Felusiak, L., Hill, C., \& Pemberton-Jones, E. J. (2015). The Importance of Developing Strategies for Employee Retention. Journal of Leadership, Accountability \& Ethics, 12(2).

Cook, D. A., \& Artino Jr, A. R. (2016). Motivation to learn: an overview of contemporary theories. Medical Education, 50(10), 997-1014. 


\section{JOURNAL OF SECURITY AND SUSTAINABILITY ISSUES ISSN 2029-7017/ISSN 2029-7025 (online) \\ 2020 Volume 9 January http://doi.org/10.9770/jssi.2020.9.J(4)}

Davydenko, V.A., Kaźmierczyk, J., Romashkina, G.F., Żelichowska, E. (2017). Diversity of employee incentives from the perspective of banks employees in Poland - empirical approach. Entrepreneurship and Sustainability Issues, 5(1), 116-126. http://doi.org/10.9770/jesi.2017.5.1(9)

Dhar, R. L. (2015). Service quality and the training of employees: The mediating role of organizational commitment. Tourism Management, 46, 419-430. https://doi.org/10.1111/medu.13074

Drucker, P. (2017). Concept of the Corporation: Routledge.

Durodolu, O. O. (2016). Technology acceptance model as a predictor of using information system'to acquire information literacy skills. Library Philosophy and Practice.

F. Hair Jr, J., Sarstedt, M., Hopkins, L., \& G. Kuppelwieser, V. (2014). Partial least squares structural equation modeling (PLS-SEM) An emerging tool in business research. European Business Review, 26(2), 106-121. https://doi.org/10.1108/EBR-10-2013-0128

Fornell, C., \& Larcker, D. F. (1981). Structural equation models with unobservable variables and measurement error: Algebra and statistics: SAGE Publications Sage CA: Los Angeles, CA.

Froese, F. J., Kim, K., \& Eng, A. (2016). Language, cultural intelligence, and inpatriate turnover intentions: Leveraging values in multinational corporations through inpatriates. Management international review, 56(2), 283-301. https://doi.org/10.1007/s11575-015-0272$\underline{5}$

Guest, D. E. (2017). Human resource management and employee well-being: Towards a new analytic framework. Human Resource Management Journal, 27(1), 22-38. https://doi.org/10.1111/1748-8583.12139

Hair, J. F., Ringle, C. M., \& Sarstedt, M. (2011). PLS-SEM: Indeed a silver bullet. Journal of Marketing theory and Practice, 19(2), 139-152. https://doi.org/10.2753/MTP1069-6679190202

Hsiung, H. H., \& Tsai, W. C. (2017). The joint moderating effects of activated negative moods and group voice climate on the relationship between power distance orientation and employee voice behavior. Applied Psychology, 66(3), 487-514. https://doi.org/10.1111/apps.12096

Jacoby, S. M. (2018). The embedded corporation: Corporate governance and employment relations in Japan and the United States: Princeton University Press. https://doi.org/10.1080/13563460701303016

Jalloh, A., \& Jalloh, A. (2016). The Effects of Motivation on Employee Performance: A Strategic Human Resource Management Approach. International Journal of Management Sciences and Business Research, 5(12).

Kanfer, R., Frese, M., \& Johnson, R. E. (2017). Motivation related to work: A century of progress. Journal of Applied Psychology, 102(3), 338. https://doi.org/10.1037/ap10000133

Kerdpitak, C. \& Jermsittiparsert, K. (2019). Human Resources Capabilities and Financial Performance: A Case of Thai Pharmaceutical Firms. Systematic Reviews in Pharmacy, 10(2), 198-207. https://doi.org/10.5530/srp.2019.2.28

Kim, S. L., \& Yun, S. (2015). The effect of coworker knowledge sharing on performance and its boundary conditions: An interactional perspective. Journal of Applied Psychology, 100(2), 575. https://doi.org/10.1037/a0037834

Kiruja, E., \& Mukuru, E. (2018). Effect of motivation on employee performance in public middle level Technical Training Institutions in Kenya. IJAME.

Larsson, J., Eriksson, P. E., \& Pesämaa, O. (2018). The importance of hard project management and team motivation for construction project performance. International Journal of Managing Projects in Business, 11(2), 275-288. https://doi.org/10.1108/IJMPB-04-2017-0035

Lorincová, S., Hitka, M., Bajzíková, L., Weberová, D. (2019). Are the motivational preferences of employees working in small enterprises in Slovakia changing in time. Entrepreneurship and Sustainability Issues, 6(4), 1618-1635. https://doi.org/10.9770/jesi.2019.6.4(5)

Marvel, M. R., Davis, J. L., \& Sproul, C. R. (2016). Human capital and entrepreneurship research: A critical review and future directions. Entrepreneurship theory and practice, 40(3), 599-626. https://doi.org/10.1111\%2Fetap.12136

Mayer, N. Z., \& Roberta, A. G. (2017). Social movement organizations: Growth, decay, and change Social Movements in an organizational society (pp. 121-142): Routledge. https://doi.org/10.1093/sf\%2F44.3.327

Masood, O., Tvaronavičienė, M., Javaria, K. (2019). Impact of oil prices on stock return: evidence from G7 countries, Insights into Regional Development 1(2): 129-137. https://doi.org/10.9770/ird.2019.1.2(4) 


\section{JOURNAL OF SECURITY AND SUSTAINABILITY ISSUES ISSN 2029-7017/ISSN 2029-7025 (online) 2020 Volume 9 January http://doi.org/10.9770/jssi.2020.9.J(4)}

Mikkelsen, M. F., Jacobsen, C. B., \& Andersen, L. B. (2017). Managing employee motivation: Exploring the connections between managers' enforcement actions, employee perceptions, and employee intrinsic motivation. International Public Management Journal, 20(2), 183-205. https://doi.org/10.1080/10967494.2015.1043166

Moodley, S., \& Hove, G. (2018). The factors affecting employee motivation and its impact on organisational performance at an engineering supplies company in Durban, Kwa-Zulu Natal. Kuwait Chapter of the Arabian Journal of Business and Management Review, 7(4), 55.

Preacher, K. J., Zyphur, M. J., \& Zhang, Z. (2010). A general multilevel SEM framework for assessing multilevel mediation. Psychological Methods, 15(3), 209. https://doi.org/10.1037/a0020141

Riley, S. M., Michael, S. C., \& Mahoney, J. T. (2017). Human capital matters: Market valuation of firm investments in training and the role of complementary assets. Strategic Management Journal, 38(9), 1895-1914. https://psycnet.apa.org/doi/10.1002/smj.2631

Sriekaningsih, A., \& Setyadi, D. (2015). The Effect of Competence and Motivation and Cultural Organization towards Organizational Commitment and Performance on State University Lecturers in East Kalimantan Indonesia. European Journal of Business and Management, 7(17), 208-220.

Sriviboon, C. \& Jermsittiparsert, K. (2019). Influence of Human Resource Practices on Thai Pharmaceutical Firm Performance with Moderating Role of Job Involvement. Systematic Reviews in Pharmacy, 10(2), 234-243. https://doi.org/10.5530/srp.2019.2.32

Teece, D., Peteraf, M., \& Leih, S. (2016). Dynamic capabilities and organizational agility: Risk, uncertainty, and strategy in the innovation economy. California Management Review, 58(4), 13-35. https://doi.org/10.1525\%2Fcmr.2016.58.4.13

Tvaronavičienè, M., Masood, O., Javaria, K. (2018). Preconditions of the Eurozone economic security: how to overcome liquidity risk and cost inefficiency in leading banks of UK and Germany, Polish Journal Of Management Studies, 18(1), 418-427 https://doi.org/10.17512/pjms.2018.18.1.31

van Woerkom, M., Bakker, A. B., \& Nishii, L. H. (2016). Accumulative job demands and support for strength use: Fine-tuning the job demands-resources model using conservation of resources theory. Journal of Applied Psychology, 101(1), 141. https://doi.org/10.1037/ap10000033

Vanek, J. (2017). The economics of workers' management: a Yugoslav case study: Routledge. https://doi.org/10.4324/9781315143590

Wong, K. K.-K. (2013). Partial least squares structural equation modeling (PLS-SEM) techniques using SmartPLS. Marketing Bulletin, 24(1), 1-32.

Zhang, Y. (2019). Discussion on how to motive and retain employees in China by exploring the factors influencing employee enthusiasm at work--applying two-factory theory in P\&G employees http://www.diva-portal.se/smash/get/diva2:1296602/FULLTEXT01.pdf

Luedech GIRDWICHAI is an Associate Professor and the President of Suan Sunandha Rajabhat University, Thailand. His research areas are Educational Research, Early Childhood Education, and Educational Administration.

Chutikarn SRIVIBOON is a Lecturer of Doctor of Philosophy Program in Development Administration, Suan Sunandha Rajabhat University, Thailand. Her research areas are Leadership, Human Resources Management, and Innovation Management.

ORCID ID: orcid.org/0000-0002-9667-3730

This work is licensed under the Creative Commons Attribution International License (CC BY).

http://creativecommons.org/licenses/by/4.0/

c) (i) Open Access 